\title{
Commercial Sphagnum peat moss is a vector for exotic ectomycorrhizal mushrooms
}

\author{
Rodolfo Enrique Ángeles-Argáiz • Andrés Flores-García • \\ Miguel Ulloa $\cdot$ Roberto Garibay-Orijel
}

Received: 6 February 2015/ Accepted: 24 September 2015/Published online: 26 September 2015

(C) Springer International Publishing Switzerland 2015

\begin{abstract}
Sphagnum peat moss is one of the most commonly used substrates for forest plant and houseplant production. It is extracted from peat bogs in the circumboreal region and exported worldwide. Commercial peat moss is pasteurized, and is therefore believed to be free of viable ectomycorrhizal propagules. We used a bioassay with Pinus montezumae to demonstrate that commercial peat moss carries viable ectomycorrhizal spores, able to form mycorrhizae. Ectomycorrhizal fungi on seedling root-tips were sequenced for phylogenetic analyses using the ITS rDNA barcode region. We found three species: Suillus brevipes, Sphaerosporella brunnea, and Thelephora terrestris. S. brevipes and T. terrestris were found as viable inoculum transported in the peat moss, while $S$.
\end{abstract}

Electronic supplementary material The online version of this article (doi:10.1007/s10530-015-0992-2) contains supplementary material, which is available to authorized users.

R. E. Ángeles-Argáiz · M. Ulloa · R. Garibay-Orijel ( $₫)$ Instituto de Biología, Universidad Nacional Autónoma de México, Tercer Circuito s/n, Ciudad Universitaria, Delegación Coyoacán, C.P. 04510 México, D.F., México e-mail: rgaribay@ib.unam.mx

\section{A. Flores-García}

Centro Nacional de Investigación Disciplinaria en Conservación y Mejoramiento de Ecosistemas Forestales, Instituto Nacional de Investigaciones Forestales Agrícolas y Pecuarias, Av. Progreso 5, Colonia Barrio de Santa Catarina, Delegación Coyoacán, C.P. 04010 Mexico, D.F., Mexico brunnea was a greenhouse contaminant. S. brevipes and T. terrestris have biological characteristics (such as heat resistant and long living spores) that facilitate their survival to the extraction, transport, and storage processes of peat moss. This allows them to colonize nursery seedlings and to become potential invasive species in plantation areas. S. brevipes and T. terrestris are two of the most introduced fungi by anthropic activities; it has been argued that the vehicle for the introductions are their pine symbionts. This is the first time it has been demonstrated that peat moss is an important vehicle for the introduction of these fungi; a fact potentially related to the pattern of introduction of these ectomycorrhizal species from the northern hemisphere to elsewhere in the world.

Keywords Sphagnum peat moss $\cdot$ Forestry $\cdot$ Exotic ectomycorrhizal mushrooms $\cdot$ Sphaerosporella brunnea $\cdot$ Suillus brevipes · Thelephora terrestris

\section{Introduction}

Ectomycorrhizal (ECM) fungi, along with many other organisms, have been transported by man outside of their natural distribution areas. Vellinga et al. (2009) recognized at least 770 species of ECM fungi introduced into foreign areas throughout the world. There is a clear pattern of ECM fungi introductions from boreal or temperate ecosystems in the northern hemisphere to temperate or tropical ecosystems in the southern 
hemisphere. A higher number of introductions has been reported in Brazil, New Zealand, and South Africa, due to an extensive forestry industry with exotic ectomycorrhizal trees (Alberton et al. 2014; Moeller et al. 2015; Vellinga et al. 2009). It is generally accepted that the vehicle of ECM fungi introduction is the transport of living plants and their roots that host these fungi in symbiosis (Vellinga et al. 2009). Dispersion of ECM fungi via forest soil has also been reported (Kaewgrajang et al. 2014; Tammi et al. 2001).

Pine species are some of the main ectomycorrhizal hosts in the northern hemisphere. This genus is one of the most important for timber and pulp production; therefore it has been widely introduced in commercial plantations outside of its natural distribution. As a consequence, the ECM fungi with which it is associated have been introduced to numerous southern ecosystems (Alberton et al. 2014; Hayward et al. 2015; Karst et al. 2014; Moeller et al. 2015; Nuñez et al. 2009). In parallel, the genus Eucalyptus is native to Australia and its ECM fungi associates have been introduced to the northern hemisphere in commercial plantations (Diez 2005; Nohura et al. 2012).

Literature on biological invasion is concentrated on plants and animals. For microorganisms, the studies are mainly focused on pathogens and parasites (Garbelotto and Pautasso 2012; Yoshida et al. 2013). There are some detailed works relating to ECM fungi for invasive species like Amanita phalloides (Pringle et al. 2009; Wolfe et al. 2010). It has been noted that Amanita, Laccaria, and the clades /lactarius-russula, /suillus-rhizopogon, and /thelephora-tomentella have been the most commonly introduced ones. This is important because within these lineages are species typically dominant in ectomycorrhizal communities (Vellinga et al. 2009), which have the ability to form long-lasting and resistant spores. In fact, the spores of Suillus and Rhizopogon exhibit increased viability over time (Bruns et al. 2008, 2010).

Several studies have compared the diversity and community structure of ECM fungi in native forests against commercial plantations (Bahram et al. 2013; Barroetaveña et al. 2007; Kourteva et al. 2003; Lothamer et al. 2014; O'Hanlon and Harrington 2012; Trocha et al. 2012). It has also been demonstrated that the positive interaction between exotic plants and their ectomycorrhizal symbionts favors their settlement and dispersion (Kaewgrajang et al. 2014; Vellinga et al. 2009). Recently, Wood et al. (2015) showed that exotic deer and marsupials disperse Suillus and Rhizopogon spores through mycophagy, facilitating invasion of pine into native forests in New Zealand. Nuñez et al. (2013) also highlighted the role of exotic wild boar and deer in the dispersion of exotic plants due to the dissemination of the spores of exotic Amphinema, Hebeloma, Melanogaster, Rhizopogon and Suillus. However, little attention has been given to the potential of nursery substrates to act as a long-distance vector for ectomycorrhizal inoculum, nor to the subsequent ecological implications.

Sphagnum peat moss is one of the main supplies for forest plant nursery production and it greatly contributes to the quality and viability of seedlings (Rentería et al. 1999). It is chosen as a function of its organic matter content, mineral content, water retention capacity, availability, and price. In forest nurseries, Sphagnum peat moss is used as a growing substrate in combination with other inert substrates, such as vermiculite, perlite, sand, and others. Peat moss is extracted from peat bogs in the circumboreal region. In this region, the low temperatures generate low decomposition rates, allowing organic matter to build up in great quantities over long periods of time. Another common substrate is forest soil; however on a commercial scale its extraction is prohibited in many countries because it inflicts severe ecosystem damage. When compared with peat moss, forest soil harbors a greater diversity and quantity of ectomycorrhizal inoculum (Tammi et al. 2001). Commercial peat moss passes through a pasteurization process, so it is believed to be free of microorganisms, including viable ECM fungal propagules. However, many ECM fungi produce spores with the ability to survive wildfires (Buscardo et al. 2010, 2012). As the peat moss is exported from northern countries to elsewhere in the world, it is therefore a potential vector for exotic ECM fungi. The objectives of this study were to determine if commercial peat moss used as a substrate in nurseries contains viable ectomycorrhizal inoculum and, if so, to identify the fungi and analyze their possible geographic origin. To achieve this, we conducted a bioassay of peat moss and other substrates with Pinus montezumae seedlings and sequenced the ITS rDNA of the mycorrhizae. 


\section{Methods}

We studied the presence and identity of viable ectomycorrhizal inoculum in a commercial Sphagnum peat moss (Peat moss Premier ${ }^{\mathrm{TM}}$ harvested from Canada), using a bioassay with $P$. montezumae, an endemic alpine white pine distributed in the Transmexican Volcanic Belt (TVB), known locally as "ocote". In Mexico, this is one of the few species able to survive near $4000 \mathrm{~m}$ altitude in the tallest mountains of central Mexico (Farjón et al. 1997). Due to human activities and climate change, $P$. montezumae numbers have diminished, putting it at serious risk. For these reasons, it is one of the main species used in reforestation programs in the mountains of central Mexico.

The bioassay was carried out in the nursery of the CENID-COMEF of the INIFAP in Mexico City. Pine seeds were purchased from a certified commercial supplier and came from the Iztaccihuatl volcano in Mexico State, which forms part of the TVB. The seeds were surface sterilized in hydrogen peroxide $(30 \%)$ with $20 \mu \mathrm{l}$ of Tween-20 in $500 \mathrm{ml}$ of water and kept in a shaker for $20 \mathrm{~min}$. They were then rinsed several times in potable water and, later, rinsed two times in distilled water. For pre-germination, they were submerged in distilled water for $24 \mathrm{~h}$. The seeds were germinated in sterile conditions, and after 2 weeks were planted in $130 \mathrm{~cm}^{3}$ rigid polyethylene Ray Leach Cone-tainers (Stuewe and Sons, Oregon). The containers were previously disinfected in $3 \%$ chlorine for $72 \mathrm{~h}$, rinsed, and finally washed with $96 \%$ alcohol.

The experiment consisted of three treatments: (1) peat moss/sterile vermiculite in equal proportions $(\mathrm{n}=150)$, (2) peat moss $(\mathrm{n}=20)$, and c) sterile vermiculite as a negative control $(n=20)$. We used sterile vermiculite as negative control because, as an inert substrate, the only possible origin for mycorrhizae in this treatment is an environmental contamination (water or air). The substrates in the containers were slightly compacted and humidified to water saturation. Two germinated seeds were then planted in each container, in order to avoid a reduction in sample size due to initial mortality. If both plants survived, one was randomly removed 3 months after germination. The experiment lasted 11 months. Plants were watered daily (around $30 \mathrm{ml}$ ) by automatic irrigators; additionally, they received $50 \mathrm{ml}$ of water weekly during the winter and $80 \mathrm{ml}$ during the summer. Each week, the container trays were spatially randomly rearranged in the greenhouse.

At the 11th month, the roots of each plant were dissected under an Olympus SZ61 microscope to extract every single mycorrhizal root system. From each plant, the mycorrhizae were grouped into morphotypes using external characters as color, shape, branching pattern, and presence of external mycelia. Ten samples of each morphotype by treatment were selected for DNA extraction and sequencing.

DNA from mycorrhizae was extracted and amplified with XNAP REDExtract-N-Amp Plant PCR mix (Sigma-Aldrich). For this, a $1 \mathrm{~mm}$ fragment of each mycorrhiza was put into a PCR tube with $10 \mu \mathrm{l}$ of extraction solution, then heated in a thermal cycler at $65{ }^{\circ} \mathrm{C}$ for $10 \mathrm{~min}$, followed by $95^{\circ} \mathrm{C}$ for $10 \mathrm{~min}$. Afterwards, $30 \mu$ of dilution solution were added and the solution was incubated for $30 \mathrm{~min}$ at room temperature. We amplified the ITS rDNA region with the primers ITS1F and ITS4 (Gardes and Bruns 1993). The PCR program was as follows: $94{ }^{\circ} \mathrm{C}$ for $3 \mathrm{~min}$, followed by 34 cycles of $94{ }^{\circ} \mathrm{C}$ for $1 \mathrm{~min}, 51{ }^{\circ} \mathrm{C}$ for $1 \mathrm{~min}, 72{ }^{\circ} \mathrm{C}$ for $1 \mathrm{~min}$, and finally $72{ }^{\circ} \mathrm{C}$ for $8 \mathrm{~min}$. The PCR products were then kept at $4{ }^{\circ} \mathrm{C}$. The quality of the amplification was reviewed by gel electrophoresis in $1 \%$ agarose. Good amplicons were cleaned with ExoSAP IT (USB Corp.) using $3.5 \mu$ of PCR product, $1 \mu \mathrm{l}$ of ExoSAP, and $1 \mu \mathrm{l}$ of water in a single cycle of $37{ }^{\circ} \mathrm{C}$ for $45 \mathrm{~min}$, and $80{ }^{\circ} \mathrm{C}$ for $15 \mathrm{~min}$. The sequencing reaction was carried out with BigDye 3.1 (Applied Biosystems), according to the manufacturer's instructions. Samples were sequenced using an ABI 3100 in the "Laboratorio de Secuenciación Genómica de la Biodiversidad y la Salud" at the Universidad Nacional Autonoma de Mexico, Biology Institute. Each sample was sequenced in both directions, using previously given PCR primers. The sequences were manually edited and assembled in Geneious R6 (Biomatters). DNA sequences were grouped into Molecular Taxonomic Operational Units (MOTUs) at $97 \%$ of genetic similarity (Peay et al. 2008). A representative sequence of each MOTU was deposited in the NCBI Genbank database with the accession numbers KC471330-KC471332.

MOTUs consensus sequences were compared to those in GenBank using the BLAST algorithm (Altschul et al. 1990). Sequences in Genbank with the highest similarities to ours were downloaded and used for phylogenetic analysis, together with 
sequences from phylogenetic treatments of each genus (Bruns et al. 2010; Perry et al. 2007; Wu et al. 2000).

To verify if $S$. brevipes and $T$. terrestris occur naturally in the center of Mexico, from 2008 to 2010 we collected sporocarps of both genera throughout the TVB, in natural temperate forests. We deposited these sporocarps in the MEXU-UNAM herbaria as voucher specimens (Online Resource 1). We extracted the DNA from vouchers as previously described, but using $20 \mu \mathrm{l}$ of extraction solution and $20 \mu \mathrm{l}$ of dilution solution. The ITS rDNA of all the vouchers was sequenced as described for mycorrhizae. Voucher sequences were deposited in the NCBI Genbank database with the accession numbers: KP697998KP698003, KC152234, KC152235, KC152237, KC152240-KC152242, and KC152244.

For each MOTU, we aligned the sequences with Muscle and conducted a Bayesian analysis within Geneious R6 with 1,100,000 iterations, GTR + I + Gamma as substitution model. For Suillus, we used $S$. flavidus FJ845439 as outgroup, for the clade /thelephora-tomentella, we used T. fuscocinerea GU214812 as outgroup, and for Sphaerosporella, we used Tricharina gilva JQ824118 as outgroup.

\section{Results}

We observed two different mycorrhizal morphotypes in the treatments, contact exploration type (CE) and middle distance exploration mat-forming type (MDEM) (Agerer et al. 2012). In the combined substrate treatment, the CE was the most common, with an average of 32 (SD 33) mycorrhizal root tips per plant and mycorrhized $88.7 \%$ of the plants; the MDEM type presented an average of 3 (SD 8) mycorrhizal root tips per plant and mycorrhized $22 \%$ of the plants. In the peat moss treatment, we observed an average of 7 (SD 10) mycorrhizal root tips per plant of the CE type mycorrhizing $60 \%$ of plants; while there was an average of 18 (SD 21) mycorrhizal root tips per plant of the MDEM type mycorrhizing $85 \%$ of plants. In the negative control, we counted an average of 14 (SD 13) mycorrhizal root tips per plant of the CE type mycorrhizing $90 \%$ of plants, while there were no MDEM mycorrhizae (Online Resource 2).

The most abundant morphotype was the CE type, with an overall average of 28 mycorrhizae per plant. It was characterized by having dichotomous branching, and transparent tips with a weak mantle. In these mycorrhizae, the root constriction gives rise to a smooth, brown mantle with few emergent hyphae (Fig. 1A, B).
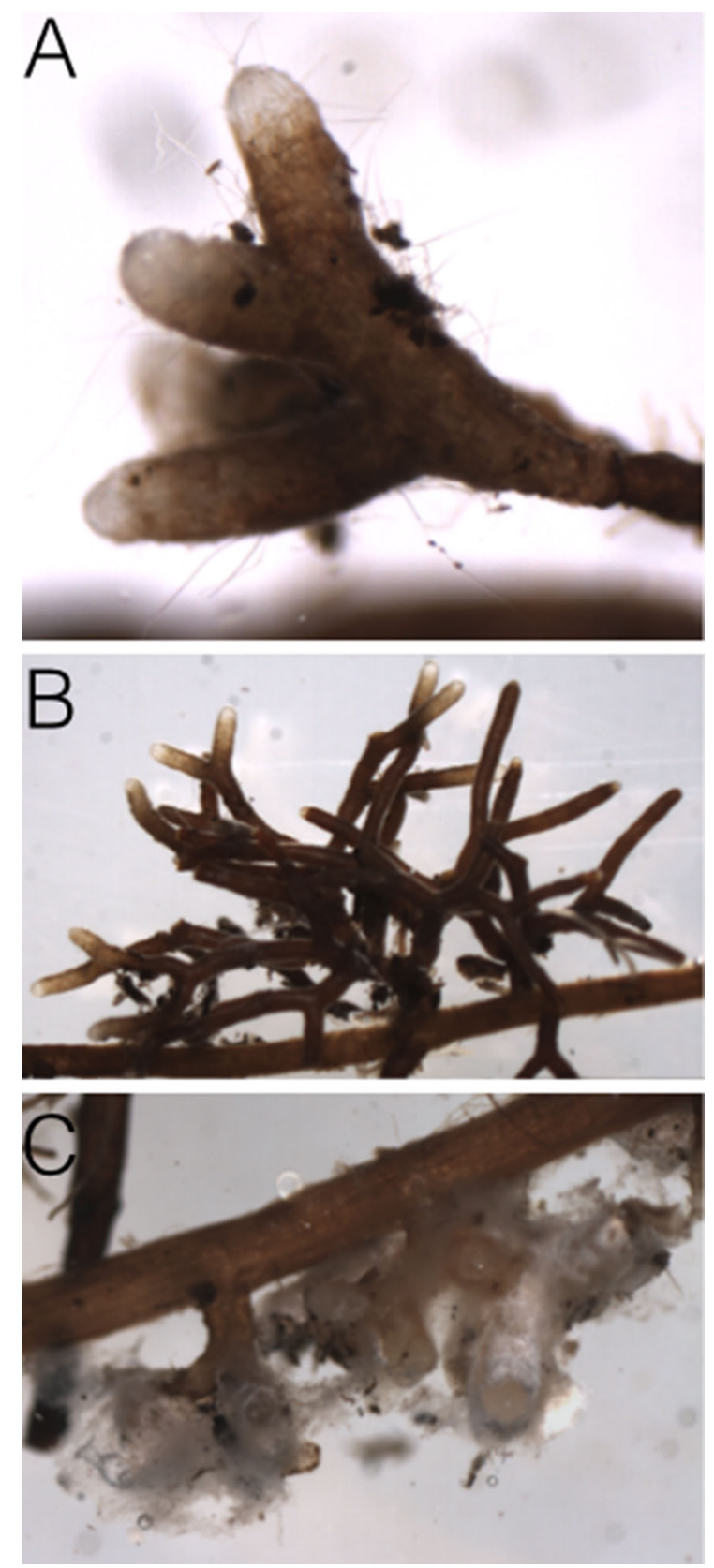

Fig. 1 Ectomycorrhizae found in the three treatments. A Sphaerosporella brunnea (EC), B Thelephora terrestris (EC), C Suillus brevipes (MDEM) 
The second morphotype, with an overall average of 7 mycorrhizae per plant, was MDEM. It presented both dichotomous and coralloid features. Single mycorrhizal systems had white cottony mantle in the older root tips, and brown mantle in the younger root tips. A white mantle usually covered the tips. Its main characteristic was the presence of dense white extraradical mycelia, often forming long rhizomorphs (Fig. 1C). All these are typical characteristics of suilloid mycorrhizae (Agerer and Rambold 20042012).

We obtained good DNA sequences for 44 samples from the three treatments; these were grouped into three different MOTUs. MOTU 1 was composed of the majority of the sequences (32) with a $99.5 \%$ genetic similarity to the species Suillus brevipes. All the S. brevipes mycorrhizae presented the MDEM type. The CE type included mycorrhizae clustered in the MOTUs 2 and 3. MOTU 2 had 8 sequences with a $99.1 \%$ genetic similarity with the species Sphaerosporella brunnea. MOTU 3 had 4 sequences with a $99.7 \%$ genetic similarity with the species Thelephora terrestris.

The Bayesian analysis for Sphaerosporella situated the peat moss sequence in a small group composed of three sequences, with a posterior probability (PP) of 0.632; this group, in turn, is part of a larger clade, which represents the species $S$. brunnea with a PP of 0.998 (Fig. 2). The Bayesian analysis for Suillus included the peat moss sequence within the betterrepresented clade (by number of sequences), which represents $S$. brevipes with a PP of 1 (Fig. 3). Almost all the sequences of the mushroom vouchers collected in the TVB belonged to $S$. pseudobrevipes. Two other Mexican voucher sequences belonged to $S$. pungens with a PP of 1 . In the Bayesian analysis of the clade /thelephora-tomentella (Fig. 4), there is a clade composed of sequences with high genetic similarity to the peat moss sequence. This clade represents $T$. terrestris and has a PP of 0.999. The Thelephora sequences from central Mexico clustered with other species such as $T$. anthocephala, T. caryophyllea. T. pseudoterrestris, and $T$. regularis.

Both S. brevipes and T. terrestris were found forming mycorrhizae in the peat moss treatment and in the peat moss/vermiculite treatment, but neither were found in the negative control. In contrast, the mycorrhizae formed by $S$. brunnea were found in all the treatments.

\section{Discussion}

Sphaerosporella brunnea, a common contaminant of nurseries

We found two mycorrhizae morphotypes; however, through molecular techniques, we found three MOTUs. From the CE type, we recovered sequences from mycorrhizae of $T$. terrestris and S. brunnea that were indistinguishable by external morphology (Fig. 1A, B). S. brunnea had mycorrhizae with "pezizoid" morphology, as characterized by Tedersoo et al. (2006), which is typical of ECM fungi from the Pezizaceae family. Mycorrhizae formed by the five lineages of ectomycorrhizal fungi in Pezizaceae with roots of Pinaceae are characterized by thin and smooth mantles in brown to reddish-brown colorations, sometimes opaque or lacquered, without cystidia or clamp connections, with frequent or infrequent arising hyphae, without rhizomorphs or mycelial mats. In concurrence with our findings, Tedersoo et al. (2006) mentioned that this morphology could be confused with those presented by the mycorrhizae of some Thelephoraceae species.

Sphaerosporella brunnea was the only ECM fungi that colonized roots of $P$. montezumae in the negative control, and was also found in the other treatments. In all cases, it formed mycorrhizae exclusively in the upper fine roots (within the first $1-1.5 \mathrm{~cm}$ of substrate). The genotype of $S$. brunnea from peat moss was included in a clade composed of sequences from North America and Europe; however, it presented $100 \%$ genetic similarity with a sequence of a pezizoid fungi (JN704819) widely distributed in the TVB forming spore banks in the Nevado de Toluca, Ajusco, Malinche, Popocatépetl, San Andrés, and Iztaccíhuatl volcanoes in central México (Garibay-Orijel et al. 2013) (Online Resource 3). This indicates that, even if $S$. brunnea is naturally distributed in North America, the genotype mycorrhizing our plants is identical to the genotype of $S$. brunnea found in central Mexico and is different from other genotypes found elsewhere. As a consequence, the inoculant of S. brunnea in our experiment came from the local environment and not from the peat moss.

Sphaerosporella brunnea is an ascomycete commonly found as a contaminant in nurseries for forest production, and may become a problem as it competes in the rhizosphere against other ECM fungi like Tuber 
(García-Montero et al. 1997). Because this was the only fungus found in our negative control colonizing the upper roots, we conclude that this species was a contaminant from the nursery transported to the plants by irrigation or the air.

Suillus brevipes, a neartic fungus potentially transported within peat moss

Suilloid mycorrhizae (MDEM) were the most abundant morphotype in the peat moss treatment, forming mycorrhizae with up to $85 \%$ of the plants (Online
Fig. 3 Phylogenetic analysis of Suillus. EC east coast, $W C$ west coast. Tall gray bar indicate $S$. brevipes, short gray bar indicate, S. pseudobrevipes, short highlighting indicate Mexican sequences, long highlighting indicate peat moss sequences

Resource 2). Phylogenetic analysis identified this fungus as a genotype of $S$. brevipes that is closely related to genotypes from Canada and the northern USA. This clade included also a sequence (JX898970) from Hawaii (Hynson et al. 2013) and another (JQ791158) from Australia (Dunk et al. 2012) (Online Resource 4), both works deal with ECM species

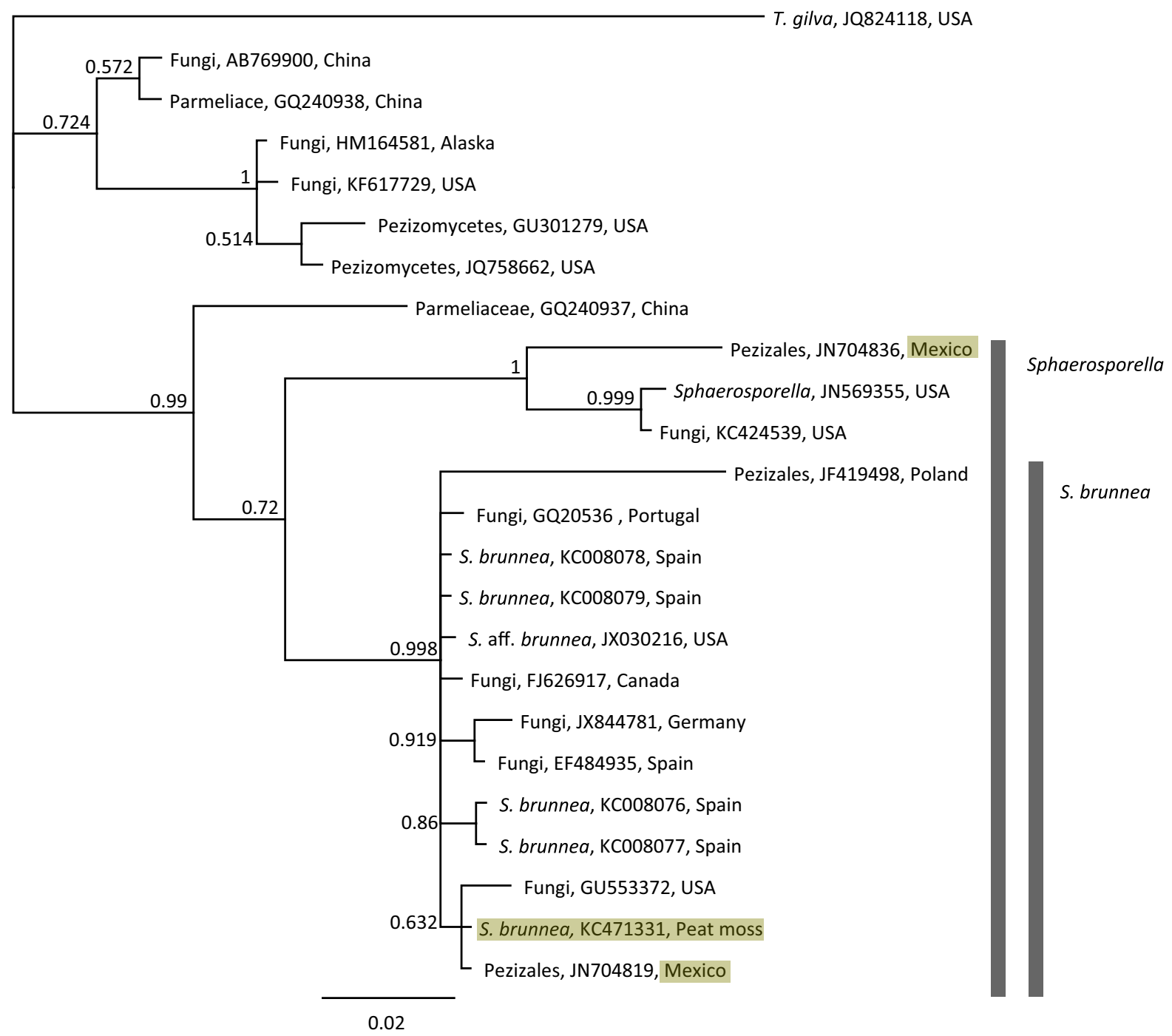

Fig. 2 Phylogenetic analysis of Sphaerosporella. Tall gray bar indicate Sphaerosporella genera, short gray bar indicate S. brunnea species, short highlighting indicate Mexican sequences, long highlighting indicate peat moss sequences 


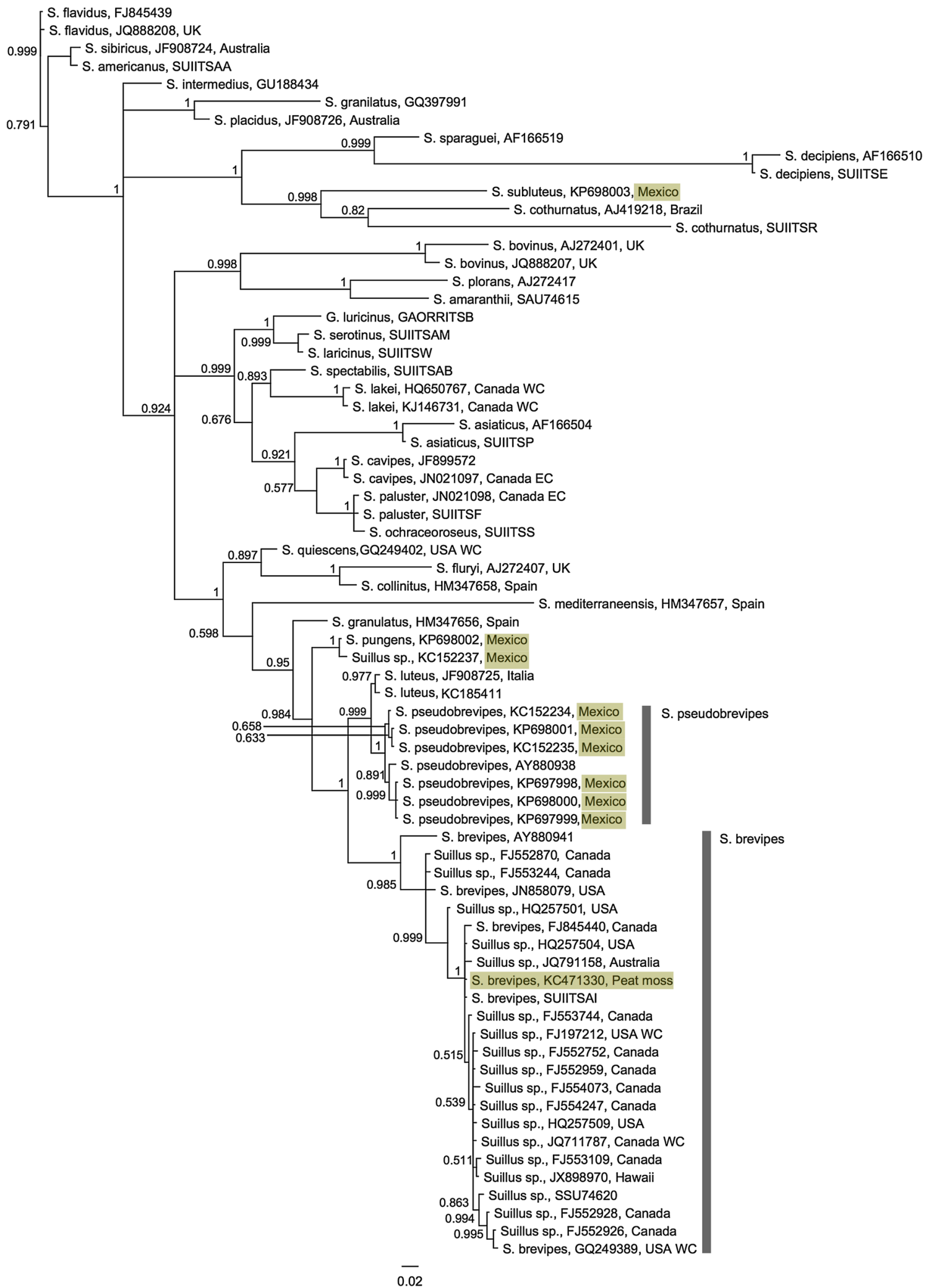


introduced in commercial pine plantations. In contrast, none of the Suillus fruit bodies sequenced from central Mexico belonged to this clade. As no MDEM mycorrhizae were found in the control treatment, we concluded that the inoculum for $S$. brevipes mycorrhizae was already present in the peat moss. This evidence demonstrates that $S$. brevipes is a neartic fungus that can be transported long distances within commercial peat moss.

In bioassays, species of this genus have shown a great capacity to become dominant in plants in single inoculation treatments (Carrera-Nieva and LópezRíos 2004); however, they are not good competitors in multiple species experiments or in the field (Gardes and Bruns 1996; Dahlberg and Stenlid 1994; Kennedy et al. 2007). In nature, when plants inoculated with Suillus are planted in areas without ectomycorrhizal inoculum in the soil, this genus can establish successfully and become dominant (el Karkouri et al. 2006; Rincón et al. 2007). Thanks to their large number of spores (Peay and Bruns 2014) and its reactivity, species of this genus are good pioneers of reclaimed forest edges or after severe disturbances where they associate with young pines producing abundant sporocarps (Gómez-Reyes et al. 2011). In mature forests, where complex ectomycorrhizal communities develop, they present low mycorrhization of their pine symbionts because they do not compete well through mycelial interactions (Gardes and Bruns 1996; Peay et al. 2011). As a consequence of these biological traits, when greenhouse pines produced in peat moss are used for reforestation within forested areas, they have little impact on the ECM community structure. However, where these plants are used for restoration or introduced in forests without ECM competitors, there is a high potential for the introduction of Suillus species, as has already happened in South America (Nuñez et al. 2009; Barroetaveña et al. 2007; Hayward et al. 2015).

Thelephora terrestris, a circumboreal fungus dominant in forest nurseries

The CE morphotype was conformed by T. terrestris and $S$. brunnea with a 1:2 proportion in the sequenced samples. T. terrestris was not present in the negative control and had an even distribution in the peat moss and the peat moss/vermiculite treatments. The
Bayesian analysis situated the $T$. terrestris genotype from peat moss with sequences of $T$. terrestris from Europe and North America while there were no sequences in this clade of mushroom vouchers collected in the TVB. As a consequence, the inoculant of $T$. terrestris was not an environmental contaminant; and, so far, we have not found this species in natural temperate forests in central Mexico. T. terrestris has a wide host range; it is associated with Betula, Picea, Pinus, Populus, Pseudotsuga, Quercus, and Salix, among other hosts (Bent et al. 2011; Chanona-Gómez et al. 2007; Menkis et al. 2005; Moeller et al. 2015; Mohan et al. 1993; Obase et al. 2007; Potvin et al. 2012). It is a fungus involved in the early ecological succession and colonization of the roots of pioneer plants, for example, after volcanic eruptions (Obase et al. 2007). It is highly competitive and a key component in the ectomycorrhizal communities in which it is involved (Pestaña-Nieto and Santolamazza 2009). It is known to compete for young pine roots directly with other genera, such as Laccaria, in coinoculation bioassays (Sudhakara and Natarajan 1997). Additionally, DNA sequences of this species have been found in the community of resistant propagules of ECM fungi, which play a key role in regeneration after a disturbance by fire (Bent et al. 2011; Buscardo et al. 2010). T. terrestris has also been reported as one of the ECM fungi more commonly found in forest nurseries in Europe (Iwanski and Rudawska 2007; Jonsson et al. 1999; Menkis and Vasaitis 2011). Our data suggest that the peat moss is a potential vector of this species to nurseries.

The boreal affinity of ectomycorrhizal mushrooms in peat moss

The DNA sequences with higher genetic similarity to our peat moss $S$. brevipes and $T$. terrestris sequences retrieved from the BLAST analysis presented interesting biogeographic patterns (Online Resources 4 and 5). Peat moss $S$. brevipes sequences were close to those from studies in the Canadian Southern Boreal Forest (Kranabetter et al. 2009a, b), and from North American sub-boreal forests (Kretzer and Bruns 1997). Our sequences of peat moss T. terrestris had $100 \%$ similarity to some from European studies: from Swedish boreal forests, from Germany associated with P. sylvestris, from France associated with Fagus (Online Resource 5), as well as from North American 


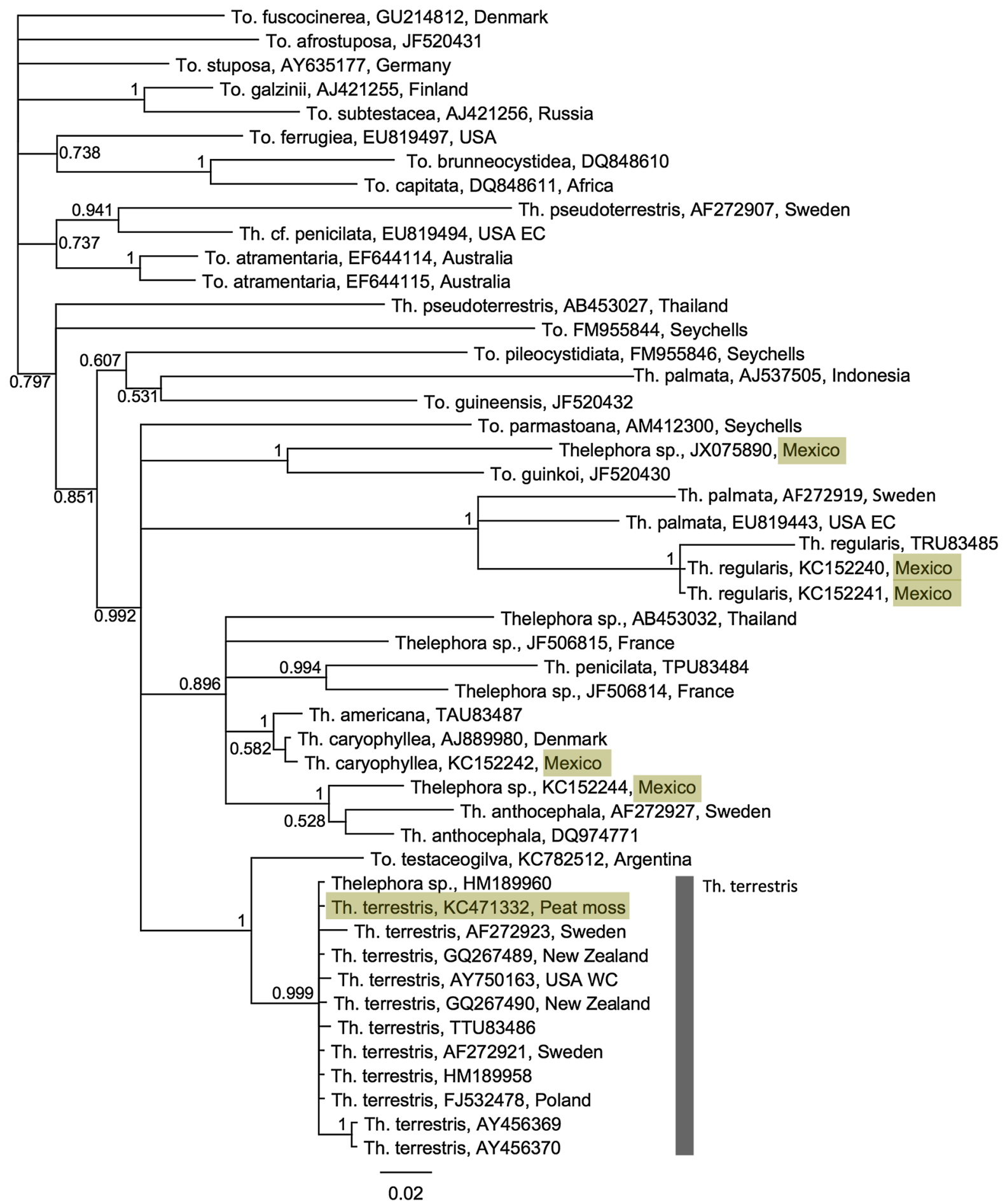

Fig. 4 Phylogenetic analysis of Thelephora. EC east coast, WC west coast. Gray bar indicate T. terrestris, short highlighting indicate Mexican sequences, long highlighting indicate peat moss sequences 
studies performed in Ontario, Canada, which report $T$. terrestris as the most abundant species in the ECM fungal community (Amend et al. 2010).

We highlight the fact that the DNA sequences from $S$. brevipes and T. terrestris mycorrhizae found in peat moss and peat moss/vermiculite treatments in this study have greater similarities with Holarctic and Nearctic sequences than with sequences of mushroom vouchers from the TVB in central Mexico. Even when these species are known to form spore banks, they are not present in the spore banks in the TVB in central Mexico, while $S$. brunnea does (Garibay-Orijel et al. 2013). This shows that the origin of the inoculum of $S$. brevipes and $T$. terrestris was not a contamination of the nursery from local air, as happened in the case of $S$. brunnea. The data indicate that the genotypes of $S$. brevipes and $T$. terrestris that formed mycorrhizae in our bioassay plants came from other locations, like the circumboreal regions where peat bogs are exploited for exportation.

Implications of the invasive potential of the ectomycorrhizal inoculum transported in peat moss

The main factors that determine success in the colonization of new areas are the genetic diversity and the population size at the first introduction event, as well as the contribution of new genetic diversity in successive introduction events (Desprez-Loustau et al. 2007). It is common for plantations to use the same substrate every year, which is acquired from the same suppliers and extracted from the same sites. Therefore, the systematic use of peat moss in commercial plantations reinforces the potential for invasion. This way, plantations get a constant supply of new genetic material of ECM fungi that build inoculum load, feed the diversity and allow a greater likelihood of invasion success.

Fungi with low host specificity in their natural ranges tend to be more successful in colonizing new hosts in the invaded ranges than those with high specificity (Wolfe and Pringle 2012). This is the case for A. phalloides, which is becoming widespread throughout North America, thanks to a host shift from pine plantations, in which it was introduced, to pines and oaks in the surrounding native forests (Pringle et al. 2009; Wolfe et al. 2010). Low specificity fungi have triggered the invasion of its Pinaceae hosts enabling the establishment of its self-seedlings in countries of the southern hemisphere, like Argentina, Brazil and New Zealand (Alberton et al. 2014; Hayward et al. 2015; Moeller et al. 2015). Early-stage ECM fungi (sensu Peay et al. 2011) also play an important role in Pinaceae invasions (Hynson et al. 2013; Hayward et al. 2015). In their natural distribution these fungi allow forest encroachment due to their spore banks formed by long-living propagules.

Both S. brevipes and T. terrestris are early stage fungi that form spore banks that are made up of longlasting resistant propagules suitable for germination after several years. Additionally, the spores of these species survive forest fires allowing them to become dominant in ECM communities after the conflagration (Buscardo et al. 2010, 2012; Motiejunaité et al. 2014; Obase et al. 2007). These characteristics may be related to the survival of the inoculum of both species in the commercial peat moss.

This work highlights the potential transportation of ECM fungal inoculum through peat moss used extensively in forest plant production across the world. The generalized use of peat moss as a substrate of forest production coincides with the recognized tendency towards biological invasion of ECM fungi from the northern hemisphere southwards (Vellinga et al. 2009).

The issue raised by this study is broadly applicable to all nurseries using peat moss as substrate. While this may not seem to be an issue if the plants are non-ECM, the nurseries and general public may re-use the peat moss for other purposes or dump in garden beds. Thus aiding the spread in local council areas, private gardens, etc., of the inoculum of potentially invasive ECM fungi.

Acknowledgments PAPIIT-UNAM IN218210-3 financed the experimental work. The MEXBOL network (CONACyT 194045, 251085) supported DNA sequencing. We are grateful to Julieta Álvarez Manjarrez for her support in the phylogenetic analysis.

\section{References}

Agerer R, Rambold G (2004-2012) DEEMY - an information system for characterization and determination of ectomycorrhizae. München, Germany. http://www.deemy.de

Agerer R, Hartmann A, Pritsch K, Raidl S, Schloter M, Verma R, Weigt R (2012) Plants and their ectomycorrhizosphere: 
cost and benefit of symbiotic soil organisms. In: Matyssek R, Schnyder H, Oßwald W, Ernst D, Munch JC, Pretzsch H (eds) Growth and defense in plants, Ecological Studies, vol 220. Springer, Heidelberg, pp 213-242

Alberton O, Aguiar D, Gimenes RMT, Carrenho R (2014) Metaanalysis for responses of eucalyptus and pine inoculated with ectomycorrhizal fungi in Brazil. J Food Agric Environ 12:1159-1163

Altschul SF, Gish W, Miller W, Myers EW, Lipman DJ (1990) Basic local alignment search tool. J Mol Biol 215:403-410

Amend AS, Seifert KA, Bruns TD (2010) Quantifying microbial communities with 454 pyrosequencing: does read abundance count. Mol Ecol 19:5555-5565

Bahram M, Kõljalg U, Kohout P, Mirshahvaladi S, Tedersoo L (2013) Ectomycorrhizal fungi of exotic pine plantations in relation to native host trees in Iran: evidence of host range expansion by local symbionts to distantly related host taxa. Mycorrhiza 23:11-19

Barroetaveña C, Cázares E, Rajchenberg M (2007) Ectomycorrhizal fungi associated with ponderosa pine and Douglasfir: a comparison of species richness in native western North American forests and Patagonian plantations from Argentina. Mycorrhiza 17:355-373

Bent E, Kiekel P, Brenton R, Taylor DL (2011) Root-associated ectomycorrhizal fungi shared by various boreal forest seedlings naturally regenerating after a fire in interior Alaska and correlation of different fungi with host growth responses. Appl Environ Microb 77:3351-3359

Bruns TD, Peay KG, Boynton PJ, Grubisha LC, Hynson NA, Nguyen NH, Rosenstock NP (2008) Inoculum potential of Rhizopogon spores increases with time over the first 4 yr of a 99-yr spore burial experiment. New Phytol 181:463-470

Bruns TD, Grubisha LC, Trappe JM, Kerekes JF (2010) Suillus quiescens, a new species commonly found in the spore bank in California and Oregon. Mycologia 102:438-446

Buscardo E, Rodríguez-Echeverría S, Martín MP, Angelis P, Pereira JS, Freitas H (2010) Impact of wild fire return interval on the ectomycorrhizal resistant propagules communities of a Mediterranean open forest. Fungal Biol 14:628-636

Buscardo E, Rodríguez-Echeverría S, Barrico L, García MA, Freitas H, Martín MP, de Angelis P, Muller LAH (2012) Is the potential for the formation of common mycorrhizal networks influenced by fire frequency? Soil Biol Biochem 46:136-144

Carrera-Nieva A, López-Ríos GF (2004) Manejo y evaluación de ectomicorrizas en especies forestales. Rev Chapingo Cienc For 10:93-98

Chanona-Gómez F, Andrade-Gallegos RH, Castellanos-Albores J, Sánchez JE (2007) Macromicetos del parque educativo Laguna Bélgica, municipio de Ocozocoautla de Espinosa, Chiapas, México. Rev Mex Biodiv 78:369-381

Dahlberg A, Stenlid J (1994) Size, distribution and biomass of genets in populations of Suillus bovinus (L.: Fr.) Roussel revealed by somatic incompatibility. New Phytol 128:225-234

Desprez-Loustau ML, Robin C, Buée M, Courtecuisse R, Garbaye J, Suffert F, Sache I, Rizzo DM (2007) The fungal dimension of biological invasions. Trends Ecol Evol 29:472-480

Diez J (2005) Invasion biology of Australian ectomycorrhizal fungi introduced with eucalypt plantations into the Iberian Peninsula. Biol Invasions 7:3-15
Dunk CW, Lebel T, Keane PJ (2012) Characterization of ectomycorrhizal formation by the exotic fungus Amanita muscaria with Nothofagus cunninghamii in Victoria, Australia. Mycorrhiza 22:135-147

El Karkouri K, Selosse MA, Mousain D (2006) Molecular markers detecting an ectomycorrhizal Suillus collinitus strain on Pinus halepensis roots suggest successful inoculation and persistence in Mediterranean nursery and plantation. FEMS Microb Ecol 55:146-158

Farjón A, Pérez de la Roza JA, Stiles ST (1997) A field guide to Pines of Mexico and Central America. The Royal Botanic Gardens, Oxford

Garbelotto M, Pautasso M (2012) Impacts of exotic forest pathogens on Mediterranean ecosystems: four case studies. Eur J Plant Pathol 133:101-116

García-Montero LG, Galán R, Massimo G, Manjón JL, Díez J (1997) Sphaerosporella brunnea (Alb et Schwein) un discomicete con incidencia en la truficultura e interés forestal. Rev Catal Micol 20:99-104

Gardes M, Bruns TD (1993) ITS primers with enhanced specificity for basidiomycetes-application for the identification of mycorrhizae and rusts. Mol Ecol 2:113-118

Gardes M, Bruns TD (1996) Community structure of ectomycorrhizal fungi in a Pinus muricata forest: above- and below-ground views. Can J Bot 74:1572-1583

Garibay-Orijel R, Morales-Marañon E, Domínguez-Gutiérrez M, Flores-García A (2013) Caracterización morfológica y genética de las ectomicorrizas formadas en un bioensayo entre Pinus montezumae y los hongos presentes en los bancos de propágulos resistentes en la Faja Volcánica Transmexicana. Rev Mex Biodiv 84:153-169

Gómez-Reyes VM, Gómez-Peralta M, Terrón-Alfonso A (2011) Efecto de las variables ambientales sobre la biomasa de macromicetos ectomicorrízicos. Biológicas 13:70-76

Hayward J, Horton TR, Nuñez MA (2015) Ectomycorrhizal fungal communities coinvading with Pinaceae host plants in Argentina: Gringos bajo el bosque. New Phytol. doi:10. 1111/nph.13453

Hynson NA, Merckx VSFT, Perry BA, Treseder KK (2013) Identities and distributions of the co-invading ectomycorrhizal fungal symbionts of exotic pines in the Hawaiian Islands. Biol Invasions 15:2373-2385

Iwanski M, Rudawska M (2007) Ectomycorrhizal colonization of naturally regenerating Pinus sylvestris L. seedlings growing in different micro-habitats in boreal forest. Mycorrhiza 17:461-467

Jonsson L, Dahlberg A, Nilsson M, Kårén O, Zackrisson O (1999) Continuity of ectomycorrhizal fungi in self-regenerating boreal forests of Pinus sylvestris: comparative analysis of diversity of mycobionts of seedlings and old trees. New Phytol 142:151-162

Kaewgrajang T, Sangwanit U, Kodama M, Yamato M (2014) Ectomycorrhizal fungal communities of Dipterocarpus alatus seedlings introduced by soil inocula from a natural forest and a plantation. J For Res 19:260-267

Karst J, Randall MJ, Gehring CA (2014) Consequences for ectomycorrhizal fungi of the selective loss or gain of pine across landscapes. Botany 92:855-865

Kennedy PG, Bergemann SE, Hortal S, Bruns TD (2007) Determining the out come of field-based competition 
between two Rhizopogon species using real-time PCR. Mol Ecol 16:881-890

Kourteva PS, Ehrenfelda JG, Häggblom M (2003) Experimental analysis of the effect of exotic and native plant species on the structure and function of soil microbial communities. Soil Biol Biochem 35:895-905

Kranabetter JM, Durall DM, Mac Kenzie WH (2009a) Diversity and species distribution of ectomycorrhizal fungi along productivity gradients of a southern boreal forest. Mycorrhiza 19:99-111

Kranabetter JM, Friesen J, Gamiet S, Kroger P (2009b) Epigeous fruiting bodies of ectomycorrhizal fungi as indicators of soil fertility and associated nitrogen status of boreal forests. Mycorrhiza 19:535-548

Kretzer A, Bruns TD (1997) Molecular revisitation of the genus Gastrosuillus. Mycologia 89:586-589

Lothamer K, Brown SP, Mattox JD, Jumpponen A (2014) Comparison of root-associated communities of native and non-native ectomycorrhizal hosts in an urban landscape. Mycorrhiza 24:267-280

Menkis A, Vasaitis R (2011) Fungi in roots of nursery grown Pinus sylvestris: ectomycorrhizal colonization, genetic diversity and spatial distribution. Microb Ecol 61:52-63

Menkis A, Vasilisuskas R, Taylor AFS, Stenlid J, Finlay R (2005) Fungal communities in mycorrhizal roots of conifer seedlings in forest nurseries under different cultivation systems, assessed by morphotyping, direct sequencing and mycelial isolation. Mycorrhiza 16:33-41

Moeller HV, Dickie IA, Peltzer DA, Fukami T (2015) Mycorrhizal co-invasion and novel interactions depend on neighborhood context. Ecology 96:2336-2347. doi:10. 1890/14-2361.1

Mohan V, Natarajan K, Ingleby K (1993) Anatomical studies on ectomycorrhizas. I. The ectomycorrhizas produced by Thelephora terrestris on Pinus patula. Mycorrhiza 3:39-42

Motiejunaité J, Adamonyte G, Irsenaite R, Juzenas S, Kasparavicius J, Kutorga E, Markovskaja S (2014) Early fungal community succession following crown fire in Pinus mugo stands and surface fire in Pinus sylvestris stands. Eur J For Res 133:745-756

Nohura ER, Hernández ML, Pastor N (2012) The species of Scleroderma from Argentina, including a new species from the Nothofagus forest. Mycologia 104:488-495

Nuñez MA, Horton TR, Simberloff D (2009) Lack of belowground mutualisms hinders Pinaceae invasions. Ecology 90:2352-2359

Nuñez MA, Hayward J, Horton TR, Amico GC, Dimarco RD, Barrios-Garcia MN, Simberloff D (2013) Exotic mammals disperse exotic fungi that promote invasion by exotic trees. PLoS ONE 8:e66832

O'Hanlon R, Harrington TJ (2012) Similar taxonomic richness but different communities of ectomycorrhizas in native forests and non-native plantation forests. Mycorrhiza 22:371-382

Obase K, Tamai Y, Yajima T, Miyamoto T (2007) Mycorrhizal associations in woody plant species at the Mt. Usu volcano, Japan. Mycorrhiza 17:209-215

Peay KG, Bruns TD (2014) Spore dispersal of basidiomycete fungi at the landscape scale is driven by stochastic and deterministic processes and generates variability in plantfungal interactions. New Phytol 204:180-191
Peay KG, Kennedy PG, Bruns TD (2008) Fungal community ecology: a hybrid beast with a molecular master. BioScience 58:799-810

Peay KG, Kennedy PG, Bruns TD (2011) Rethinking ectomycorrhizal succession: Are root density and hyphal exploration types drivers of spatial and temporal zonation? Fungal Ecol 4:233-240

Perry BA, Hansen K, Pfister DH (2007) A phylogenetic overview of the family Pyronemataceae (Ascomycota, Pezizales). Mycol Res 11:549-571

Pestaña-Nieto M, Santolamazza SC (2009) Characterization of juvenile maritime pine (Pinus pinaster Ait.) ectomycorrhizal fungal community using morphotyping, direct sequencing and fruit bodies sampling. Mycorrhiza 19:91-98

Potvin LR, Richter DL, Jugensen MF, Dumroese RK (2012) Association of Pinus banksiana Lamb. and Populus tremuloides Michx. seedling fine roots with Sistotrema brinkmannii (Bres.) J. Erikss. (Basidiomycotina). Mycorrhiza 22:631-638

Pringle A, Adams RI, Cross HB, Bruns TD (2009) The ectomycorrhizal fungus Amanita phalloides was introduced and is expanding its range on the west coast of North America. Mol Ecol 18:817-833

Rentería AA, Jimenez HC, Landa JA (1999) Efecto de seis sustratos sobre la germinación de Pinus patula Sch. et Cham., P. montezumae Lamb. y P. pseudostrobus Lindl. en condiciones de vivero. Foresta Veracruzana 1:31-34

Rincón A, de Felipe MR, Fernández-Pascual M (2007) Inoculation of Pinus halepensis Mill. with selected ectomycorrhizal fungi improves seedling establishment 2 years after planting in a degraded gypsum soil. Mycorrhiza 18:23-32

Sudhakara MR, Natarajan K (1997) Coinoculation efficacy of ectomycorrhizal fungi on Pinus patula seedlings in a nursery. Mycorrhiza 7:133-138

Tammi H, Timonen S, Sen R (2001) Spatiotemporal colonization of Scot pine roots by introduced and indigenous ectomycorrhizal fungi in forest humus and nursery Sphagnum peat microcosms. Can J For Res 31:746-756

Tedersoo L, Hansen K, Perry BA, Kjoller R (2006) Molecular and morphological diversity of pezizalean ectomycorrhiza. New Phytol 170:581-596

Trocha SK, Kałucka I, Stasinska M, Nowak W, Dabert M, Leski T, Rudawska M, Oleksyn J (2012) Ectomycorrhizal fungal communities of native and non-native Pinus and Quercus species in a common garden of 35-year-old trees. Mycorrhiza 22:121-134

Vellinga EC, Wolfe BE, Pringle A (2009) Global patterns of ectomycorrhizal introductions. New Phytol 181:960-973

Wolfe BE, Pringle A (2012) Geographically structured host specificity is caused by the range expansions and host shifts of a symbiotic fungus. ISME J 6:745-755

Wolfe BE, Richard F, Cross HB, Pringle A (2010) Distribution and abundance of the introduced ectomycorrhizal fungus Amanita phalloides in North America. New Phytol 185:803-816

Wood JR, Dickie IA, Moeller HV, Peltzer DA, Bonner KI, Rattray G, Wilmshurst JM (2015) Novel interactions between non-native mammals and fungi facilitate establishment of invasive pines. J Ecol 103:121-129 
Wu QX, Mueller GM, Lutzoni FM, Huang YQ, Guo SY (2000) Phylogenetic and biogeographic relationships of eastern Asian and eastern north American disjunct Suillus species (Fungi) as inferred from nuclear ribosomal RNA ITS sequences. Mol Phylogenet Evol 17:37-47
Yoshida K, Schuenemann VJ, Cano LM, Pais M, Mishra B, Sharma R, Lanz C, Martin FM, Kamoun S, Krause J, Thines M, Weigel D, Burbano HA (2013) The rise and fall of the Phytophthora infestans lineage that triggered the Irish potato famine. eLife 2:e0731. doi:10.7554/eLife.00731 